\title{
Education for Clean and Healthy Lifestyle in Preventing Covid-19 for Elementary School Students 1 Maleber Ciamis
}

\author{
Dewi Afrtianti ${ }^{1}$, Grida Saktian Laksito ${ }^{2 *}$ \\ ${ }^{I}$ Research Colaboratory Community, Bandung, Indonesia \\ ${ }^{2}$ School of Social and Economics Development, Universiti Malaysia Terengganu, Malaysia \\ *Corresponding author email: gridasaktianlaksito@gmail.com
}

\begin{abstract}
The implementation of education regarding healthy clean living behavior is a form of community service, with the aim of being able to help elementary school students to increase their understanding of the importance of maintaining clean and healthy behavior to avoid the spread of the Covid-19 virus. COVID-19 causes a disease that attacks the respiratory system in humans. This virus has infected millions of people, causing a high mortality rate for sufferers throughout the world, both children and adults so that education about clean and healthy living behavior is one form of prevention to avoid the Covid-19 virus. The method of activity in this community service uses a follow-up study method with a participatory approach. The educational materials provided to the students of SD 1 Maleber include an introduction to COVID-19 and its symptoms, how to wash hands properly and correctly, how to apply cough etiquette, how to apply physical distancing, and how to apply a clean and healthy lifestyle. Educational activities are carried out by providing counseling to PHBS by using lecture, discussion, question and answer methods, and demonstrations. Submission of material is also done using learning media in the form of posters. The results of this study are to provide knowledge of participants who are students of Elementary School 1 Maleber Ciamis where previously they felt indifferent and felt they did not maintain clean and healthy behavior. After participating in educational activities for clean and healthy living habits, students will understand the importance of maintaining a healthy and clean lifestyle, gain knowledge in preventing the spread of the COVID-19 virus by applying cough etiquette, washing hands thoroughly, maintaining distance, and always maintaining health.
\end{abstract}

Keywords: Healthy Clean Lifestyle, Education, Covid-19

\section{Introduction}

Improving the quality of the younger generation is something that can be a priority for a nation, to prepare good human resources. The quality of the younger generation is strongly supported by aspects of physical, mental, and social health. Optimal health for early childhood will form a generation with a strong immune system against disease and a generation of children's intelligence (Hillemeier et al., 2013; Watts et al., 2012). Early childhood represents a golden period for children to develop and learn. Because this period represents a valuable time for a child in identifying various realities in the surrounding area, thereby triggering his personality, psychomotor, cognitive, and social growth. Therefore, it is necessary to carry out early childhood education in the form of stimulation provided by parents, teachers and the surrounding environment to optimize children's developmental abilities, so that they can grow and develop according to their own stages (Isong et al., 2012; Celik and Pancoe, 2012).

Clean and healthy living behavior is behavior that is carried out by following regulations related to personal health. The main purpose of a clean and healthy lifestyle is to improve health through a gradual process of raising awareness of citizens in understanding the process of clean living, the explanation describes personal position in maintaining clean and healthy living behavior every day (Bitsko et al., 2016). The school's clean and healthy lifestyle describes a series of prevention efforts made by the school community against diseases, produces a clean and healthy area, and improves their health (King and Norton, 2018). Clean and healthy living behavior is carried out on the basis of education that allows individuals, groups and citizens to independently help themselves in health and plays a very valuable role in achieving the health of citizens (Duell et al., 2015; Brusseau and Hannon, 2015).

Through daily activities at school, information about a clean and healthy lifestyle is disseminated to early childhood children as quickly as possible. The greater the role of the principal in providing information about clean and healthy living behaviors, the more children will be able to practice in school (Putri et al., 2019). Schools also 
participate in the formation of students' clean and healthy behavior to improve health and support the achievement of learning objectives. Therefore, the Ministry of Education and Culture aims to improve the quality of learning and student achievement by creating a clean and healthy area. One measure of character education development is cleanliness and health, which is tied to this learning role, schools become learning facilities in having a clean and healthy area, which also provides encouragement for a good educational process.

Corona Virus Disease 2019 or COVID-19 is a new type of disease caused by infection with the Severe Acute Respiratory Syndrome Coronavirus 2 (SARS COV-2) or known as the novel coronavirus (2019-nCoV) (Singhal, 2020). From its initial appearance at the end of 2019 until May 20, 2020, this disease has infected 4,789,205 people and caused the death of 318,789 people worldwide (WHO 2020). This disease is transmitted through droplets (splashes) when talking, coughing, and sneezing from people infected with the Corona virus. In addition, this disease can also be transmitted through physical contact (touch or handshake) with sufferers and touching the face, mouth and nose with hands exposed to the Corona virus (Setiawan and Iasha, 2020).

Clinical symptoms that appear due to infection with this virus include symptoms of the common cold (fever, cough, runny nose, sore throat, muscle aches, headaches) to severe complications (diarrhea and pneumonia) that can lead to death (Huang et al., 2020). Children belong to the age group that is very vulnerable to COVID-19 transmission from the surrounding environment. Some children who are infected with COVID-19 often do not show symptoms of infection (Zimmermann and Curtis, 2020).

Maintaining a healthy lifestyle is very important from an early age, because children are susceptible to disease, and children's immune systems are not as good as adults. Not only that, children usually put their fingers in their mouths, whatever they touch and try to eat, they don't know if the objects are dirty or contain bacteria, when children can't maintain their hygiene and health.

Clean and Healthy Living Behavior is a set of behaviors that are practiced on the basis of awareness as a result of learning that makes a person, family, group or community able to help themselves (independently) in the health sector and play an active role in realizing public health (Regulation of the Minister of Health of the Republic of Indonesia Number 2269). According to Rozi et al (2021), Clean and healthy living behavior for the prevention of the COVID-19 virus can be in the form of good and correct hand washing, how to apply cough etiquette, how to do Physical Distancing (maintaining physical distance), and how to maintain personal hygiene. Providing education about PHBS can be done through counseling.

By implementing Clean and Healthy Living Behavior in schools by students, teachers and the school community, it will shape them to have the ability and independence to prevent disease, improve their health, and play an active role in creating a healthy school environment (Wechsler et al., 2020). Health promotion through the school community is the most effective as an effort to develop healthy living behaviors. Schools are formal educational institutions so that it is possible to inculcate knowledge for the emergence of behavior through regulations. School children are the most sensitive group to accept change or renewal (easy to be guided, directed, and instilled) in healthy living habits.

Extension is basically a communication process and a process of behavior change through education, so that extension activities can achieve the maximum results to be achieved when the learning methods and media used are in accordance with the intended target, which is expected to change children's knowledge of Clean and Healthy Living Behavior good (Centeio et al., 2018).

Based on the results of direct observations of the initial survey and interviews with principals and teachers on May 20, 2021 at Elementary School Maleber 1 Ciamis which had 122 students from grades one to 6, it was found that students at Elementary School Maleber 1 Ciamis still littered, did not understand the importance of exercising, not understanding the criteria for healthy snacks, not understanding the importance of washing hands with soap, and not knowing the importance of weighing and measuring height regularly, still not caring about the cleanliness of the latrine and not keeping the distance between students when class ends.

Based on research conducted by Putra et al. (2021), stated that there was an effect of counseling on PHBS and the use of masks on increasing students' knowledge and attitudes at SDN 005 Binuang during the covid-19 pandemic. Similar things are also found in research conducted by Zukmadini et al. (2020), the education provided by the facilitator can increase the knowledge of the orphanage children on clean and healthy living behavior in the prevention of COVID-19. This can be seen from the percentage of participants' knowledge before being given education, which is $74.48 \%$ which then increases to $86.49 \%$ after being given education. The map location elementary school Maleber 1 Ciamis can be seen in Figure 1. 


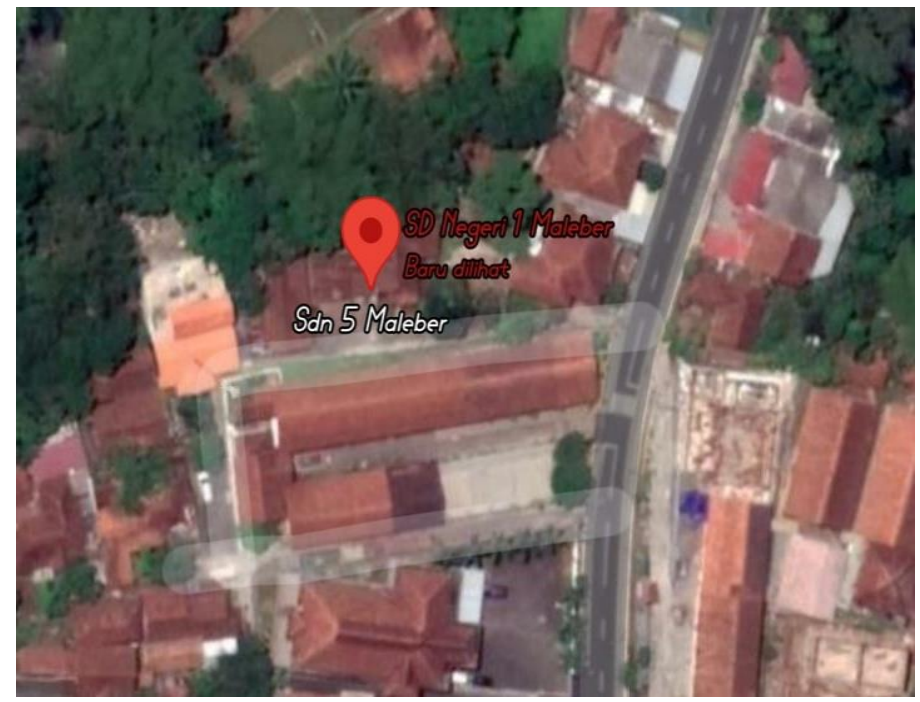

Figure 1 Map Location Elementary School Maleber 1 Ciamis

The purpose of this community service is to help the students of Elementary School Maleber 1 Ciamis in implementing a clean and healthy lifestyle. Some of the things the team did in this service activity were to provide socialization of understanding about the dangers of the Covid-19 virus and its symptoms, how to wash hands properly and correctly, how to apply cough etiquette, how to apply physical distancing, and how to apply a clean and healthy lifestyle. an introduction to the dangers of the COVID-19 virus and its symptoms, how to wash hands properly and correctly, how to apply cough etiquette, how to apply physical distancing, and how to apply a clean and healthy lifestyle.

\section{Methodology}

The implementation of the service activity will take place on May 20, 2021 at SD Maleber 1 Ciamis which is located on Jl. Siliwangi No.97, Maleber, Kec. Ciamis, Ciamis Regency, West Java 46214, The target of this community service program is 52 children or elementary school children consisting of grades 3 to 6 . The elementary school Maleber 1 Ciamis can be seen in Figure 2.

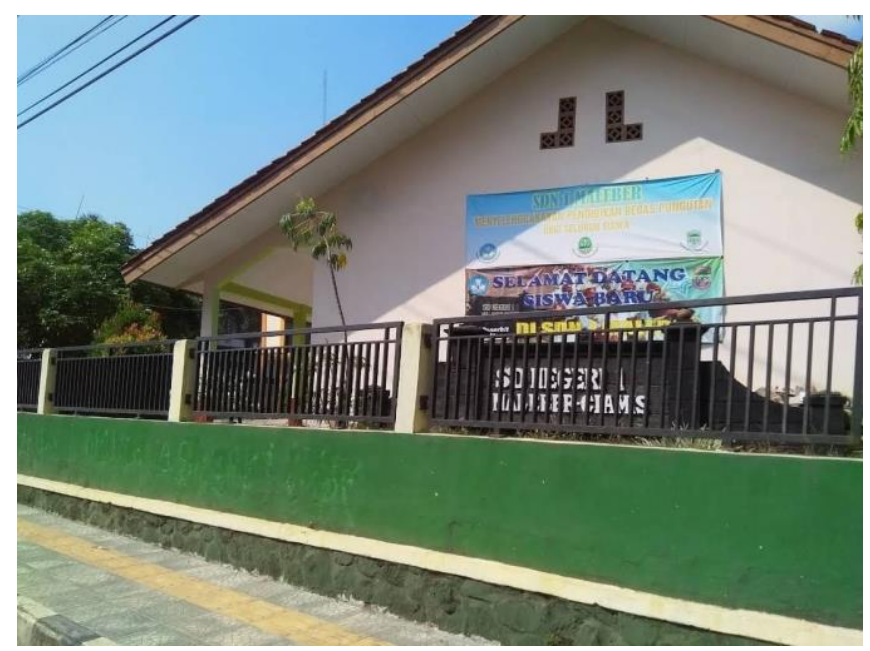

Figure 2 Elementary School Maleber 1 Ciamis

The method used in the implementation of PKM activities is socialization with counseling techniques in the form of lectures or presenting material in the form of theories and posters related to simple hygiene practices, questions and answers, and games, including:

- Observation Step 
This activity is carried out as the beginning of the activity with the aim of obtaining a description of the condition of the intended student; namely by holding a meeting with the Principal of Elementary School Malebar 1 Ciamis, namely Mrs. Siti Sadiah, S.Pd

- Socialization stage

At this stage, the service team will provide and explain the service plan that will be carried out so that time and various technical needs can be arranged in connection with the overall implementation of the training.

- Implementation Stage

The implementation of community service is carried out in collaboration with the Malebar 1 Ciamis Elementary School. In this counseling, these students will be given an explanation about the importance of saving for the achievement of their goals in the future. The Community Service Programs that we carry out at Elementary School Malebar 1 Ciamis include: introduction to the dangers of the COVID-19 virus and its symptoms, how to wash hands properly and correctly, how to apply cough etiquette, how to apply physical distancing, and how to apply a clean lifestyle and healthy.

\section{Results And Discussion}

We carry out these activities while still carrying out the Covid-19 health protocol recommended by the government, namely by wearing masks, washing hands and maintaining distance. Before starting our activities, we conducted a Covid 19 Health Protocol Check and Participant Registration. This outreach activity began with a speech from the Principal, which was followed by a presentation of the material and a question and answer discussion with the participants.

There are 2 resource persons who come from group members who take turns delivering material. The first resource person, Reni Nuraeni, explained about the dangers of the Covid-19 virus and how to prevent it. Meanwhile, the second resource person, Fatimah Sujana, explained about easy practices that students can do in maintaining cleanliness and explained the importance of clean and healthy lifestyle behavior by using poster media.

In this material, game interludes are also provided which can provide additional education to participants so that they better understand the concept of a clean and healthy lifestyle and maintain their focus in listening to the material presented and to avoid boredom. During service activities there are difficulties or obstacles in its implementation, namely where on the day of implementation, many participants were unable to attend, this happened because there were still many children who were not allowed to leave the house due to the Covid 19 pandemic. The second obstacle was that the situation during the delivery of the material was still not conducive because participants were always talking to their friends and playing together. causing the focus of other participants on the delivery of the material to be disturbed, disturbing what was conveyed by the resource person. The practice of a clean and healthy lifestyle carried out by the participants can be seen in Figure 3.
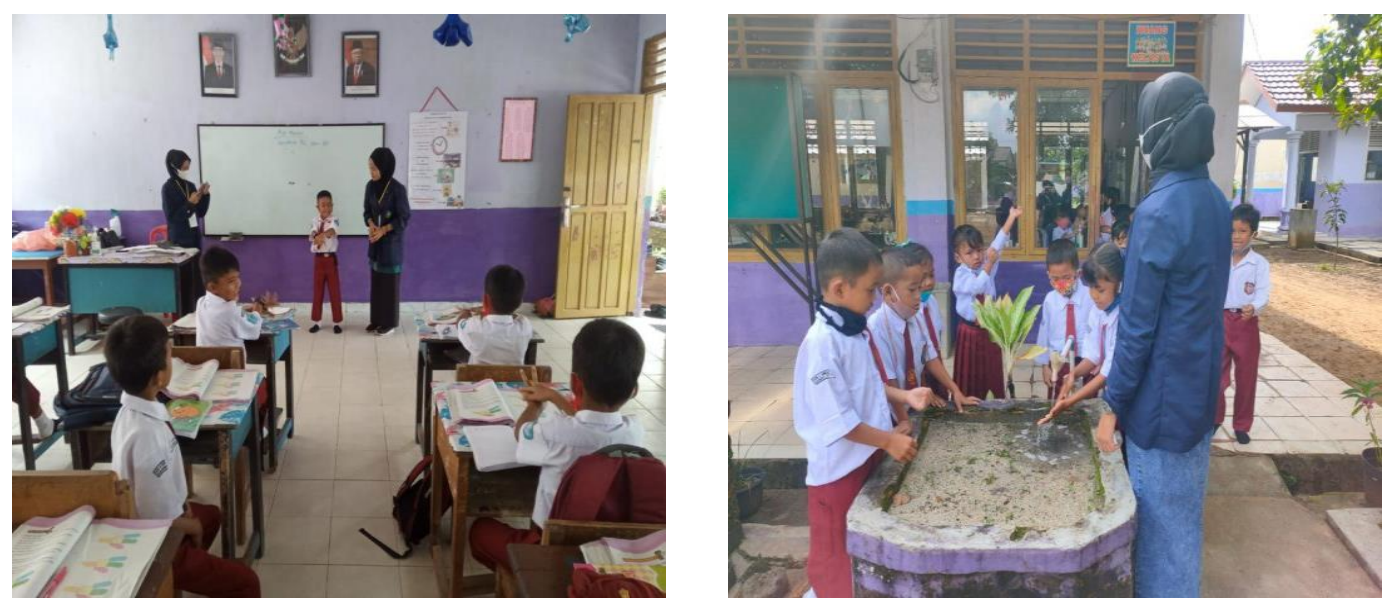

Figure 3 The practice of a Clean and Healthy Lifestyle carried out by the participants

The end of this material is by practicing good toothbrushing, good cough etiquette, and washing hands with soap as recommended by the ministry of health so as to avoid the Covid-19 virus. In this activity, followed by 52 students from grades 3-6, some of the participants were very enthusiastic about asking and answering the questions given by the organizing committee, then at the end of the implementation by giving souvenirs and taking photos with the socialization participants. 


\section{Conclussion}

This outreach activity has increased understanding of the importance of carrying out and implementing a clean and healthy lifestyle in all student activities so that participants who are Maleber 1 Ciamis students grow interest in maintaining cleanliness in the school environment and always apply a clean and healthy lifestyle so that they avoid the dangers of the Covid-19 virus.

It is recommended that the application of a clean and healthy lifestyle for early childhood should be accompanied and fully supported by parents, teachers and by health institutions such as health centers so that children can get used to implementing a clean and healthy lifestyle. Instilling interest in healthy lifestyles in children from an early age is expected to be able to regenerate the habits of Indonesia's young generation.

\section{Acknowledgments}

We hope that with this community service the participants who are students of grades 3 to 6 Elementary School Maleber 1 Ciamis can routinely apply the steps that have been given regarding the Clean and Healthy Lifestyle. So that the knowledge gained is always useful for now and in the future.

\section{References}

Brusseau, T. A., \& Hannon, J. C. (2015). Impacting Children's Health and Academic Performance through Comprehensive School Physical Activity Programming. International Electronic Journal of Elementary Education, 7(3), 441-450.

Celik, L. A., \& Pancoe, D. L. (2012). Healthy school environment: effectiveness of hand washing instruction in an elementary school setting. NASN School Nurse, 27(4), 194-196.

Centeio, E. E., Somers, C. L., Moore, E. W. G., Kulik, N., Garn, A., Martin, J., \& McCaughtry, N. (2018). Relationship between academic achievement and healthy school transformations in urban elementary schools in the United States. Physical Education and Sport Pedagogy, 23(4), 402-417.

Duell, P., Wright, D., Renzaho, A. M., \& Bhattacharya, D. (2015). Optimal health literacy measurement for the clinical setting: a systematic review. Patient education and counseling, 98(11), 1295-1307.

Hillemeier, M. M., Lanza, S. T., Landale, N. S., \& Oropesa, R. S. (2013). Measuring early childhood health and health disparities: a new approach. Maternal and child health journal, 17(10), 1852-1861.

Huang, C., Y. Wang, and X. Li. (2020). Clinical Features of Patients Infected with 2019 Novel Coronavirus in Wuhan. China Lancet, 395, 497-506.

Isong, I. A., Luff, D., Perrin, J. M., Winickoff, J. P., \& Ng, M. W. (2012). Parental perspectives of early childhood caries. clinical Pediatrics, 51(1), 77-85.

King, C., \& Norton, D. (2017). Does therapeutic positioning of preterm infants impact upon optimal health outcomes? A literature review. Journal of Neonatal Nursing, 23(5), 218-222.

Putra, A. I., Puteri, A. D., \& Yusmardiansah, Y. (2021). Pengaruh Penyuluhan Mengenai Phbs Dan Penggunaan Masker Terhadap Peningkatan Pengetahuan Dan Sikap Siswa Di Sdn 005 Binuang Pada Masa Pandemi Covid-19. Jurnal Kesehatan Tambusai, 2(4), 78-88.

Putri, R. M., Y. Rosdiana, and A. C. Nisa. 2019. Application of Clean and Healthy Living Behavior from the Household Knowledge and Attitude Study. Journal Of Nursing Practice, 1(3), 39-49.

Rozi, Fathor, Zubaidi Ahmad, and Masykuroh. (2021). Strategi Kepala Sekolah Dalam Menerapkan Program Perilaku Hidup Bersih Dan Sehat (PHBS) Pada Anak Usia Dini. Jurnal Pendidikan Anak, 10(1), 59-68.

Singhal, T. (2020). A Review of Coronavirus Disease-2019 (COVID-19). The Indian Journal of Pediatrics, 4(87), $281-86$.

Setiawan, B., \& Iasha, V. (2020). Corona virus disease 2019: the perspective opinion from pre-service elementary education teacher. Education, Sustainability \& Society (ESS), 3(2), 47-50.

Watts, S. O., Piñero, D. J., Alter, M. M., \& Lancaster, K. J. (2012). An Assessment of nutrition education in selected counties in New York State elementary schools (kindergarten through fifth grade). Journal of nutrition education and behavior, 44(6), 474-480. 
Wechsler, H., Devereaux, R. S., Davis, M., \& Collins, J. (2000). Using the school environment to promote physical activity and healthy eating. Preventive medicine, 31(2), S121-S137.

WHO. 2020. “Coronavirus Disease (COVID-19) Situation Report-121.”WHO. Retrieved (https://www.who.int/docs/defaultsource/coronaviruse/situation-reports/20200520-COVID-19-sitrep-121.pdf?sfvrsn=c4be2ec6_4,).

Zimmermann, P., and N. Curtis. (2020). Coronavirus Infections in Children Including COVID-19. The Pediatric Infectious Disease Journal, 5(39), 355-68.

Zukmadini, A. Y., Karyadi, B., \& Kasrina, K. (2020). Edukasi Perilaku Hidup Bersih dan Sehat (PHBS) dalam Pencegahan Covid-19 kepada Anak-anak di Panti Asuhan. Jurnal Pengabdian Magister Pendidikan IPA, 3(1), 1-17. 